\title{
Astragaloside IV increases MMP-2 mRNA and protein expression in human lung cancer A549 cells
}

\author{
CHIN-CHENG SU ${ }^{1,2}$, TSRONG-LAANG CHIOU ${ }^{2}$, MING-HUAN CHAN ${ }^{2}$ and JAUNG-GENG LIN ${ }^{3}$ \\ ${ }^{1}$ Division of General Surgery, Buddhist Tzu Chi General Hospital Hualien, No. 707; ${ }^{2}$ Tzu Chi University, No. 701, \\ Sec. 3, Chung Yang Road, Hualien 970; ${ }^{3}$ School of Chinese Medicine, China Medical University. \\ No. 91, Hsueh-Shih Road, Taichung City 404, Taiwan, R.O.C.
}

Received September 22, 2008; Accepted November 3, 2008

DOI: 10.3892/mmr_00000070

\begin{abstract}
Lung cancer is the leading cause of cancer-related death in Taiwan. In the clinical treatment of lung cancer patients in Asia, an Astragalus-based herbal mixture is commonly used in conjunction with chemotherapy. The principal component of Astragalus (also known as Huang-qi) is Astragaloside IV. The Astragaloside IV marker has been qualified for the phytochemicals of Astragalus. The recurrence and metastasis of lung cancer are positively correlated with matrix metalloproteinase-2 (MMP-2) mRNA and protein expression. This study examined the effects of Astragaloside IV on the mRNA and protein expression of MMP-2 in lung cancer A549 cells by RT-PCR and Western blotting. The cytotoxicity of Astragaloside IV in these cells was determined using CellTiter $96^{\circledR}$ AQueous One Solution Reagent and the MTT assay. A549 cells were treated for different durations with Astragaloside IV concentrations of 10, 20, 50 and $100 \mathrm{ng} /$ $\mathrm{ml}$. The respective proliferation rates per amount (relative to the control) were as follows: $24 \mathrm{~h}, 96.85 \pm 1.12,95.63 \pm 0.83$, $93.92 \pm 0.84,95.27 \pm 0.57 \%$; $48 \mathrm{~h}, 98.86 \pm 1.56,95.71 \pm 0.59$, $94.09 \pm 0.68,93.44 \pm 0.5 \% ; 72 \mathrm{~h}, 99.48 \pm 0.16,95.60 \pm 0.48$, $95.23 \pm 0.67,94.72 \pm 1.12 \%$. MMP-2 mRNA expression as well as vascular endothelial growth factor mRNA expression were upregulated at concentrations of 10,20 and $50 \mathrm{ng} / \mathrm{ml}$. Additionally, protein expression of MMP-2 was increased at concentrations of 10,20 and $30 \mu \mathrm{g} / \mathrm{ml}$ after $24 \mathrm{~h}$ of treatment. These results indicate that Astragaloside IV upregulates MMP-2 mRNA and protein expression in A549 cells, and therefore that it may increase recurrence and metastatic rates in lung cancer. This issue should be further examined in the clinical setting.
\end{abstract}

Correspondence to: Dr Chin-Cheng Su, Division of General Surgery, Buddhist Tzu Chi General Hospital Hualien, No. 707, Sec. 3, Chung Yang Road, Hualien 970, Taiwan, R.O.C.

E-mail:succ.maeva@msa.hinet.net

Key words: Astragaloside IV, human lung cancer A549 cells, matrix metalloproteinase-2

\section{Introduction}

Astragalus membranaceus (Leguminosae), also known as Huang-qi in Chinese, is an important 'Qi tonic' herb first recorded in the classical treatise Shen Nong Pen Tsao Ching (circa A.D. 100). It has been prescribed for centuries for general debility and to increase stamina and the overall vitality of the immune system, as well as for spleen deficiency symptoms such as a lack of appetite, fatigue and diarrhea. Additionally, Astragalus tonifies the lungs and is used in cases of frequent colds and shortness of breath (1). Currently, it is known to demonstrate a wide range of immunopotentiating effects (2-4) and to be efficacious as an adjunct cancer therapy in order to potentiate the activity and reduce the adverse toxicities of chemotherapeutic agents, inhibit recurrences and prolong survival time (5-7). Astragalus components include Astraisoflavan, Astragaloside I-VII, Astraperocarpan, Formononetin, Ononin, Soyasaponin-I, D-ß-asparagine, calycosin and cycloastragenol (8). The Astragaloside IV marker has been qualified for the phytochemicals of Astragalus (9).

Cancer metastasis, which involves multiple processes and various cytophysiological changes, is one of the primary causes of cancer-related death. It has been reported that silibinin inhibits the invasion of human lung cancer cells by decreasing production of matrix metalloproteinase (MMP)-2 (10). Another study demonstrated that inhibition of MMP-2 and -9 activity by ONO-4817 suppressed lung metastasis (11). MMP-2 may play an important role in A549 cell migration with laminin$10 / 11$ through an $\alpha 3 \beta 1$ integrin-dependent pathway (12). It has also been well documented that MMPs play an integral role in tumor spread and the metastatic cascade; human fibrosarcoma cells aggregate platelets via mechanisms that are mediated, in part, by MMP-2 (13).

According to a 2004 report from the 'People's Health Bureau of Taiwan', lung cancer is the leading cause of cancerrelated death in the country. Astragalus root (Radix Astragali) has been clinically administered to many lung cancer patients post-operatively and/or following chemotherapy or radiotherapy. Though its functions are controversial, there is no available information addressing whether the herb affects the metastasis and recurrence of lung cancer. Hence, in the present study, we investigated the effects of Astragaloside IV on MMP-2 messenger ribonucleic acid (mRNA) and protein expression in human lung cancer A549 cells. 


\section{Materials and methods}

Chemicals and reagents. Astragaloside IV $\left(\mathrm{C}_{41} \mathrm{H}_{68} \mathrm{O}_{14}\right)$ was obtained from Fluka BioChemika (74777). The human lung cancer A549 cell line was obtained from the Food Industry Research and Development Institute (Hsinchu, Taiwan). Tris- $\mathrm{HCl}$ was purchased from Sigma Chemical Co. (St. Louis, MO, USA), TE buffer from Merck Co. (Darmstadt, Germany) and penicillin-streptomycin, trypsin-EDTA, fetal bovine serum and glutamine from Gibco BRL (Grand Island, NY, USA). The CellTiter 96 AQueous One Solution Cell Proliferation Assay, TRIzol Reagent and the Reverse Transcription System were purchased from Promega Corp. (USA). Gene Taq DNA polymerase was purchased from Blossom Biotechnologies Inc. (Taiwan cat no. GP500), while MMP-7 and -2, along with vascular endothelial growth factor (VEGF) primers, were purchased from Mission Biotech (Taiwan). Minimum essential medium (MEM) was purchased from Hyclone (cat. no. SH30008.01).

The A549 human lung cancer cell line. Human lung cancer A549 cells were placed into $25-\mathrm{cm}^{2}$ tissue culture flasks and maintained in MEM supplemented with $10 \%$ heat-inactivated fetal bovine serum, $100 \mathrm{U} / \mathrm{ml}$ penicillin and $100 \mu \mathrm{g} / \mathrm{ml}$ streptomycin at $37^{\circ} \mathrm{C}$ in a humidified atmosphere of $95 \%$ air and $5 \% \mathrm{CO}_{2}$.

Cell proliferation. A549 cells were plated in 96-well plates at a density of $2 \times 10^{4}$ cells/well and grown for $24 \mathrm{~h}$. Various concentrations of Astragaloside IV were then added to the cells for final concentrations of 10, 20, 50 and $100 \mathrm{ng} / \mathrm{ml}$, while MEM (solvent) alone was added for the control. Cells were then grown at $37^{\circ} \mathrm{C}$ in $5 \% \mathrm{CO}_{2}$ and $95 \%$ air for $24 \mathrm{~h}, 48$ and $72 \mathrm{~h}$. In order to determine cell proliferation, CellTiter 96 AQueous One Solution Reagent ( $20 \mu 1 /$ well) was added, and the plates were incubated for $2 \mathrm{~h}$ at $37^{\circ} \mathrm{C}$ in a humidified $5 \%$ $\mathrm{CO}_{2}$ atmo-sphere. Absorbance was recorded at $490 \mathrm{~nm}$ using a 96-well plate reader. All cultures were assayed in triplicate.

Reverse transcriptase polymerase chain reaction (RT-PCR). A549 cells $\left(5 \times 10^{6} / \mathrm{ml}\right)$ were treated with or without various concentrations $(0,10,20$ and $50 \mathrm{ng} / \mathrm{ml})$ of Astragaloside IV for $24 \mathrm{~h}$. Total RNA was extracted from the cells using TRIzol Reagent, then $1 \mu \mathrm{g}$ of the total RNA, $0.5 \mu \mathrm{g}$ oligo(dT) $)_{15}$ primer, $10 \mu \mathrm{M}$ dNTP mixture and diethyl pyrocarbonate-treated water were combined in a microcentrifuge tube at a final volume of $20 \mu 1$. The entire mixture was heated at $70^{\circ} \mathrm{C}$ for $5 \mathrm{~min}$ and chilled on ice for at least $5 \mathrm{~min}$. Reverse transcription was conducted using the Reverse Transcription System (Promega) according to the manufacturer's instructions. Reverse transcription products from the total RNA served as the template for PCR. For the amplification of target cDNA, the following components were combined in a $25 \mu 1$ solution: $25 \mathrm{mM}$ $\mathrm{MgCl}_{2}, 10 \mathrm{mM}$ dNTP, $10 \mu \mathrm{M}$ primer, Taq DNA polymerase, Reverse Transcription 10X buffer and first-strand cDNA reaction nuclease-free water. Primer sequences were: MMP-2 forward 5'-TGCGGTTTTCTCGAATCCAT-3' and reverse 5'-GGAGTCCGTCCTTACCGTCAA 3'; MMP-7 forward 5'-GGTCACCTACAGGATCGTATCATAT-3' and reverse 5'-CATCACTGCATTAGGATCAGAGGAA-3'; VEGF

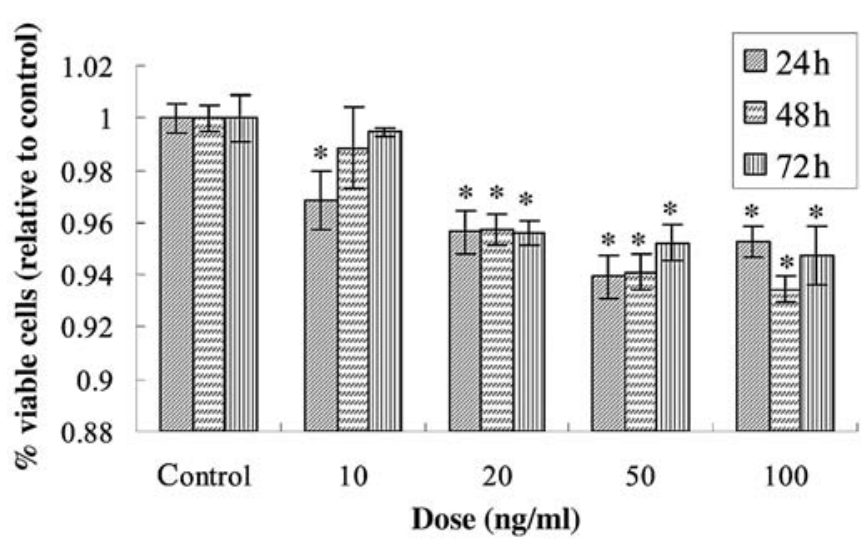

Figure 1. Cytotoxicity of Astragaloside IV on A549 cells. A549 cells were plated in 96-well plates at a density of $2 \times 10^{4}$ cells/well and grown for $24 \mathrm{~h}$. Various concentrations of Astragaloside IV were then added to the cells for final concentrations 10, 20, 50 and $100 \mathrm{ng} / \mathrm{ml}$, while MEM (solvent) alone was added for the control. Cells were then grown at $37^{\circ} \mathrm{C}$ in $5 \% \mathrm{CO}_{2}$ and $95 \%$ air for 24, 48 and $72 \mathrm{~h}$. To determine cell proliferation, Cell Titer 96 AQueous One Solution Reagent was used as described in Materials and methods. Data represent the mean $\pm \mathrm{SD} .{ }^{*} \mathrm{P}<0.05$, significant difference. All samples were assayed in triplicate.

forward 5'-GGGGGATCCGCCTCCGAAACCATGAAC TT-3' and reverse 5'-CCCGAATTCTCCTGGTGAGAG ATCTGGTT-3'; and $B$-actin forward 5'-ACCGCTCGT TGCCAATAGTGATGA-3' and reverse 5'-CTGGCT GGCCGGCACCTGACA-3'.

Synthesis and analysis of RT-PCR products. RT-PCR products were synthesized using the Access RT-PCR System (Promega). Briefly, the RT-PCR conditions were $45 \mathrm{~min}$ at $45^{\circ} \mathrm{C}$ followed by $2 \mathrm{~min}$ at $94^{\circ} \mathrm{C}(\mathrm{RT})$, then $1 \mathrm{~min}$ at $94^{\circ} \mathrm{C}$, $1 \mathrm{~min}$ at $58^{\circ} \mathrm{C}$ and $1 \mathrm{~min}$ at $72^{\circ} \mathrm{C}$ (PCR) for 35 cycles. The PCR products $(8 \mu \mathrm{l})$ were analyzed using $3 \%$ agarose gel electrophoresis, and were readily visible by UV transillumination of an ethidium bromide-stained gel. The optical intensities of the PCR products were analysed using a Gel-Pro Analyzer image system. B-actin mRNA, which has been shown to be unaffected by stimulation, was measured in both normal and stimulated RNA samples at each point using the same cDNA. Integrated optical density (IOD) measurement of 10 separate $ß$-actin samples did not vary $>10 \%$ from the mean IOD, which is an expected variation resulting from experimental technique. For the target genes MMP-2, VEGF, MMP-7 and B-actin, the PCR product size was 605, 550, 373 and 294 bp, respectively.

Cell viability assay. Astragaloside IV concentrations in the A549 cells were increased to $2.5,5,20$ and $30 \mu \mathrm{g} / \mathrm{ml}$, and cytotoxicity was determined using the MTT assay. Briefly, $1 \times 10^{4}$ A549 cells in $200 \mu 1$ media per well were plated onto a 96-well plate and incubated at $37^{\circ} \mathrm{C}$ in $5 \% \mathrm{CO}_{2}$ overnight to allow cells to attach to the wells. Various concentrations of Astragaloside IV dissolved in DMSO were added to each well followed by incubation at $37^{\circ} \mathrm{C}$ in $5 \% \mathrm{CO}_{2}$ for 24,48 and $72 \mathrm{~h}$ to allow the drug to take effect. MTT solution was made at $5 \mathrm{mg} / \mathrm{ml} \mathrm{PBS}$, and $200 \mu \mathrm{l}$ of the solution was added to each well. Incubation was carried out at $37^{\circ} \mathrm{C}$ in $5 \% \mathrm{CO}_{2}$ for $4 \mathrm{~h}$ to allow the MTT to be metabolized. The media was discarded and formazan (the MTT metabolic product) was resuspended 

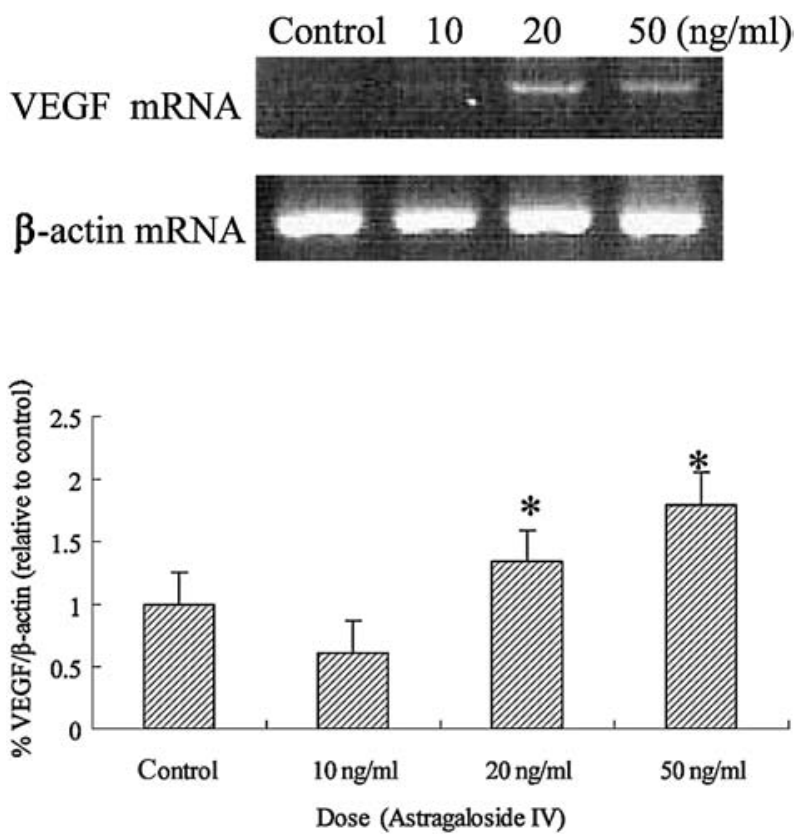

Figure 2. Representative RT-PCR showing changes in the levels of VEGF mRNA expression in A549 cells after exposure to Astragaloside IV. A549 cells $\left(5 \times 10^{6} / \mathrm{ml}\right)$ were treated with or without Astragaloside IV concentrations of $0,10,20$ and $50 \mathrm{ng} / \mathrm{ml}$ for $24 \mathrm{~h}$. Total RNA was extracted from the cells using the protocol specific to TRIzol Reagent. RT-PCR was conducted and determined as described in Materials and methods. Data represent the mean $\pm \mathrm{SD}$. ${ }^{*} \mathrm{P}<0.05$, significant difference. All samples were assayed in triplicate.

in $200 \mu 1 \mathrm{DMSO}$ then placed on a shaking table at $150 \mathrm{rpm}$ for $5 \mathrm{~min}$ to thoroughly combine it with the solvent. Optical density was read at $560 \mathrm{~nm}$, and background noise was subtracted at $590 \mathrm{~nm}$.

Cell cycle analysis. The percentages of cells in the sub-G1, G0/G1, S and G2/M phases were determined by flow cytometry as previously described (14). Briefly, $1 \times 10^{6}$ cultured A549 cells in 10-cm dishes were treated with 10, 20 and $30 \mu \mathrm{g} / \mathrm{ml}$ of Astragaloside IV for $48 \mathrm{~h}$. The harvested cells were washed twice with PBS, gently fixed with ice-cold $70 \%$ ethanol overnight and then resuspended in PBS containing $40 \mu \mathrm{g} / \mathrm{ml}$ propidium iodide, $0.1 \mathrm{mg} / \mathrm{ml} \mathrm{RNase}$ (Sigma) and $0.1 \%$ Triton $\mathrm{X}-100$. The cells were maintained at $37^{\circ} \mathrm{C}$ for $30 \mathrm{~min}$, and the cell cycle was analyzed by a flow cytometer (Becton-Dickinson, San Jose, CA, USA) equipped with an argon laser at $488 \mathrm{~nm}$.

Protein preparation. For protein extraction, $2 \times 10^{6}$ A549 cells were seeded onto $10-\mathrm{cm}$ cultured dishes and treated with 10 , 20 and $30 \mu \mathrm{g} / \mathrm{ml}$ of Astragaloside IV for $24 \mathrm{~h}$ before being harvested by centrifugation. Proteins were extracted as previously described (15). Briefly, cell pellets were resuspended in modified RIPA buffer (50 mM Tris- $\mathrm{HCl}, \mathrm{pH} 7.5,150 \mathrm{mM}$ $\mathrm{NaCl}, 1 \%$ Nonidet $\mathrm{p}-40,0.25 \%$ sodium deoxycholate, $1 \mathrm{mM}$ EGTA, $1 \mathrm{mM}$ DTT, $1 \mathrm{mM}$ PMSF, $1 \mathrm{mM}$ sodium orthovanadate, $1 \mathrm{mM}$ sodium fluoride, $5 \mu \mathrm{g} / \mathrm{ml}$ aprotinin, $5 \mu \mathrm{g} / \mathrm{ml}$ leupeptin and $5 \mu \mathrm{g} / \mathrm{ml}$ antipain) for $30 \mathrm{~min}$ at $4^{\circ} \mathrm{C}$. Lysates were immediately centrifuged at $13,000 \mathrm{x}$ g for $20 \mathrm{~min}$ at $4^{\circ} \mathrm{C}$, and the supernatant was collected, aliquoted (50 $\mu \mathrm{g} / \mathrm{tube})$ and

\section{Control $10 \quad 20 \quad 50(\mathrm{ng} / \mathrm{ml})$

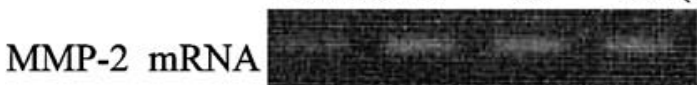
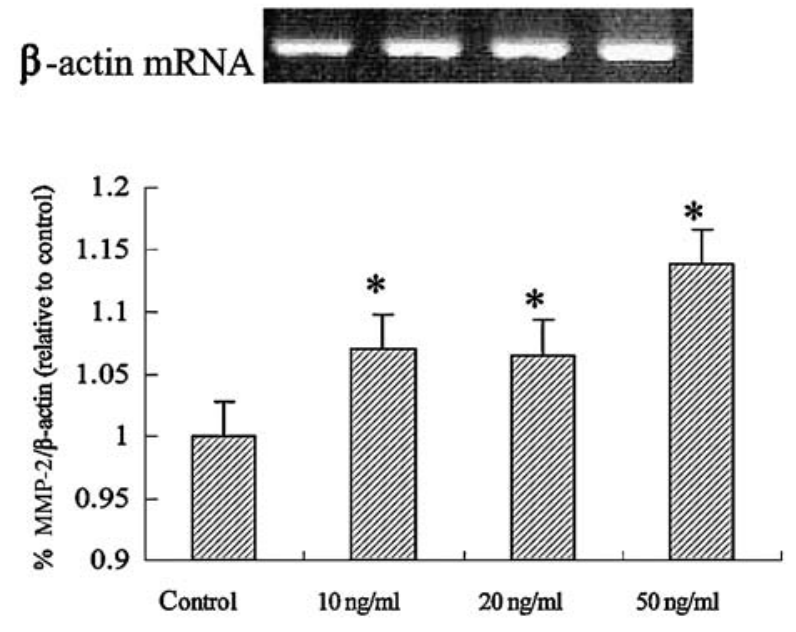

Figure 3. Representative RT-PCR showing changes in the levels of MMP-2 mRNA expression in A549 cells after exposure to Astragaloside IV. A549 cells $\left(5 \times 10^{6} / \mathrm{ml}\right)$ were treated with or without Astragaloside IV concentrations of $0,10,20$ and $50 \mathrm{ng} / \mathrm{ml}$ for $24 \mathrm{~h}$. Total RNA was extracted from the cells using the protocol specific to TRIzol Reagent. RT-PCR was conducted and determined as described in Materials and methods. Data represent the mean $\pm \mathrm{SD} .{ }^{*} \mathrm{P}<0.05$, significant difference. All samples were assayed in triplicate.

stored at $-80^{\circ} \mathrm{C}$ until used for assay. The extracted protein concentrations were determined using the Bradford method (16).

Western blotting. All protein samples were separated by $12 \%$ sodium dodecylsulfate polyacrylamide gel electrophoresis (SDS-PAGE) (Bio-Rad Life Science Products, Hercules, CA, USA) as previously described (15). The SDS-separated proteins were then equilibrated in transfer buffer $(50 \mathrm{mM}$ Tris, pH 9.0, $40 \mathrm{mM}$ glycine, $0.375 \%$ SDS and $20 \%$ methanol) and transferred onto an Immobilon-P membrane (Millipore Corp., Bedford, MA, USA). The membranes were incubated with $5 \%$ nonfat dry milk in Tris-buffered saline containing $0.05 \%$ Tween-20 for $1 \mathrm{~h}$, then washed and incubated with appropriate dilutions of specific antibodies such as VEGF, NF-кBp65, MMP-2 and B-actin (Upstate Biotechnology, Lake Placid, NY, USA) at $4^{\circ} \mathrm{C}$ overnight. After incubation with anti-mouse peroxidase-conjugated antibody (Santa Cruz, CA, USA), the immunoreactive bands were visualized with an enhanced chemiluminescence detection kit (ECL, Amersham Pharmacia Biotech). B-actin was used as an internal control.

Statistical analysis. The significance of the differences between results was assessed using the Student's t-test. P-values $<0.05$ were considered significant. All samples were assayed in triplicate.

\section{Results}

Cytotoxic effects of Astragaloside IV on A549 cells. The results of cell proliferation indicate that concentrations of 
A

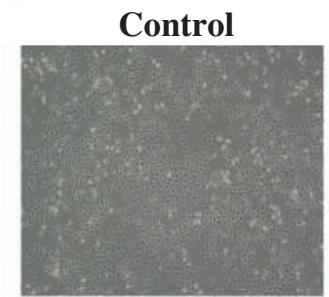

$10 \mu \mathrm{g} / \mathrm{ml}$

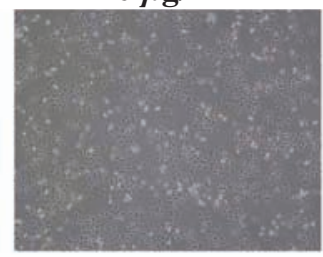

Control

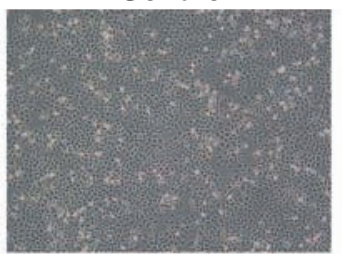

$10 \mu \mathrm{g} / \mathrm{ml}$

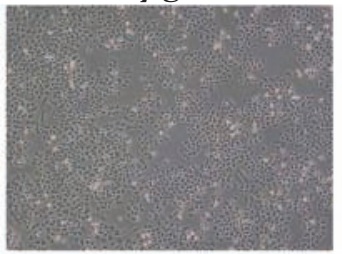

Control

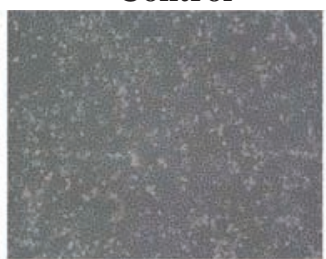

$10 \mu \mathrm{g} / \mathrm{ml}$

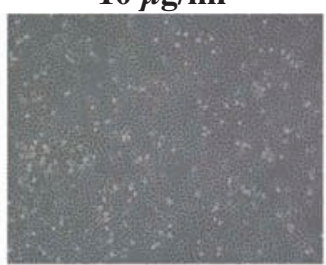

$2.5 \mu \mathrm{g} / \mathrm{ml}$

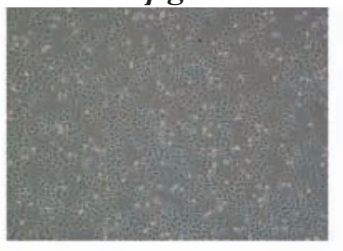

$20 \mu \mathrm{g} / \mathrm{ml}$

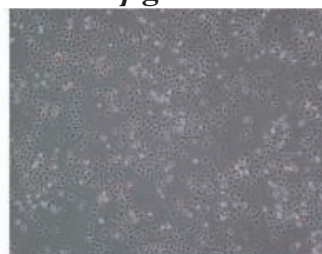

$2.5 \mu \mathrm{g} / \mathrm{ml}$

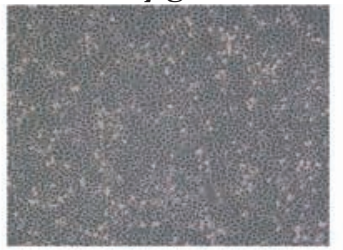

$20 \mu \mathrm{g} / \mathrm{ml}$

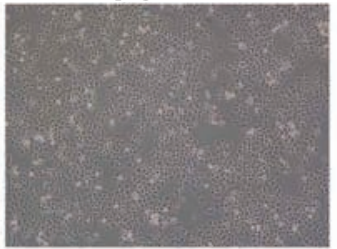

$2.5 \mu \mathrm{g} / \mathrm{ml}$

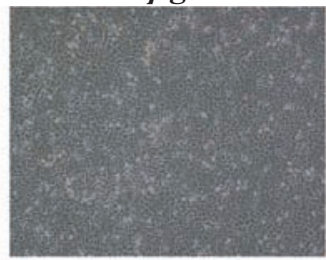

$20 \mu \mathrm{g} / \mathrm{ml}$

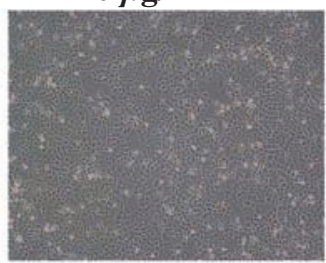

$5 \mu \mathrm{g} / \mathrm{ml}$

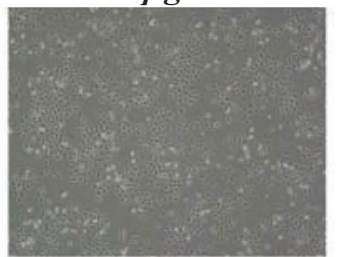

$30 \mu \mathrm{g} / \mathrm{ml}$

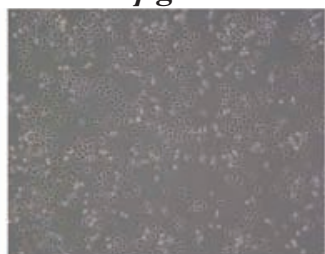

$5 \mu \mathrm{g} / \mathrm{ml}$

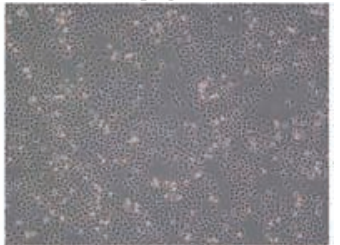

$30 \mu \mathrm{g} / \mathrm{ml}$

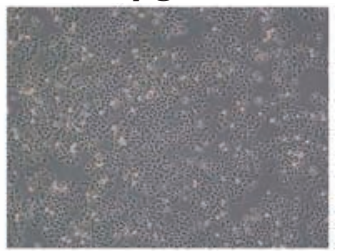

$5 \mu \mathrm{g} / \mathrm{ml}$

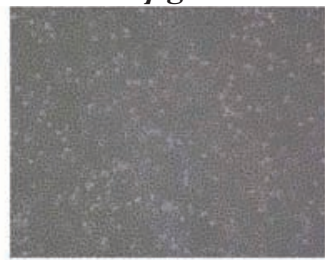

$30 \mu \mathrm{g} / \mathrm{ml}$

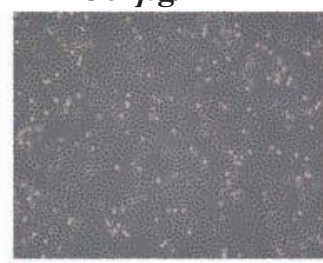

D

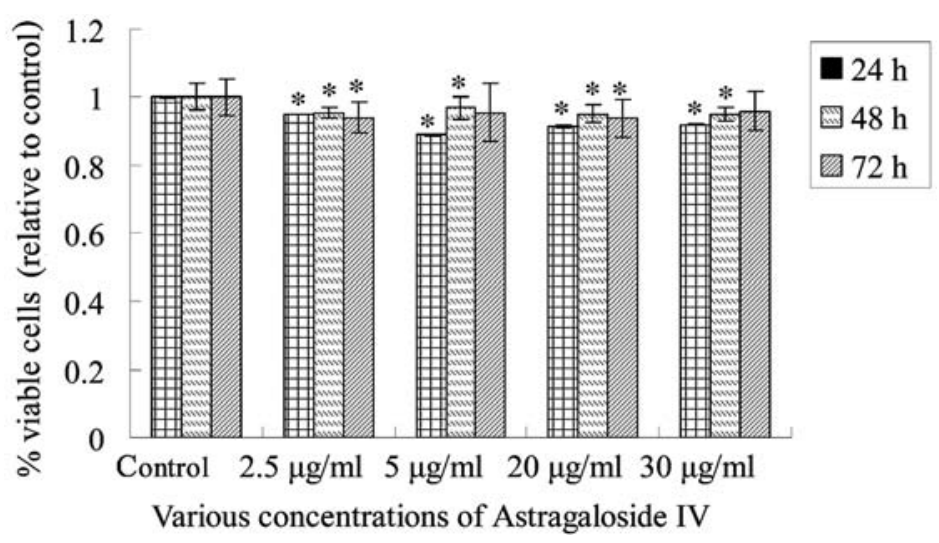

Figure 4. A549 cells were treated with increased Astragaloside IV concentrations of 0, 2.5, 5, 20 and $30 \mu \mathrm{g} / \mathrm{ml}$ for (A) $24 \mathrm{~h},(\mathrm{~B}) 48 \mathrm{~h}$ and (C) $72 \mathrm{~h}$. The results were viewed under a contrast-phase microscope (x100) (D) The cytotoxicity of Astragaloside IV in A549 cells was determined using the MTT assay as described in Materials and methods. Astragaloside IV significantly inhibited A549 cell growth. Each point is the mean \pm SD of three experiments. ${ }^{*}<0.05$. 

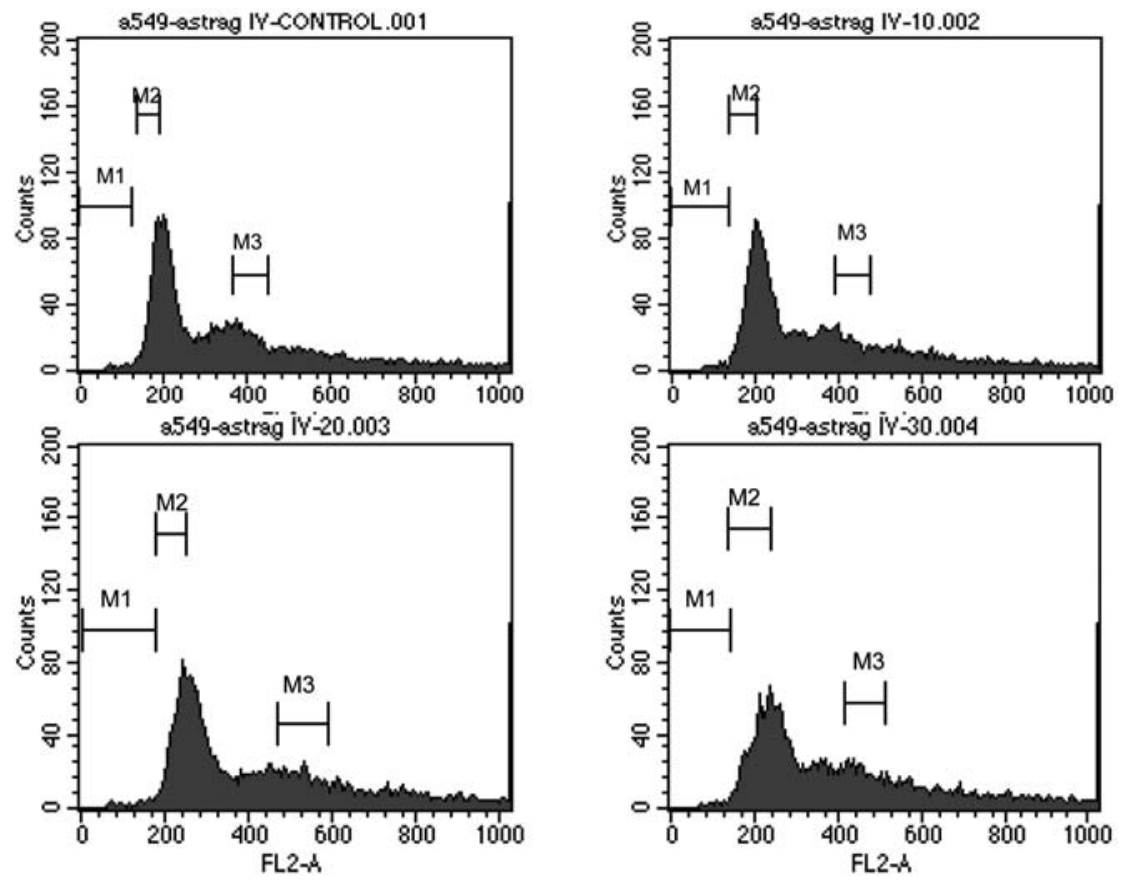

Figure 5. A549 cells were exposed to Astragaloside IV concentrations of 10, 20 and $30 \mu \mathrm{g} / \mathrm{ml}$ for $48 \mathrm{~h}$. The cells were harvested and cell cycle analysis was performed by flow cytometry as described in Materials and methods. The percentages of cells in the sub-G1 phase exhibited a significant increase after treatment with 10,20 and $30 \mu \mathrm{g} / \mathrm{m}$ of Astragaloside IV for $48 \mathrm{~h}$.

A
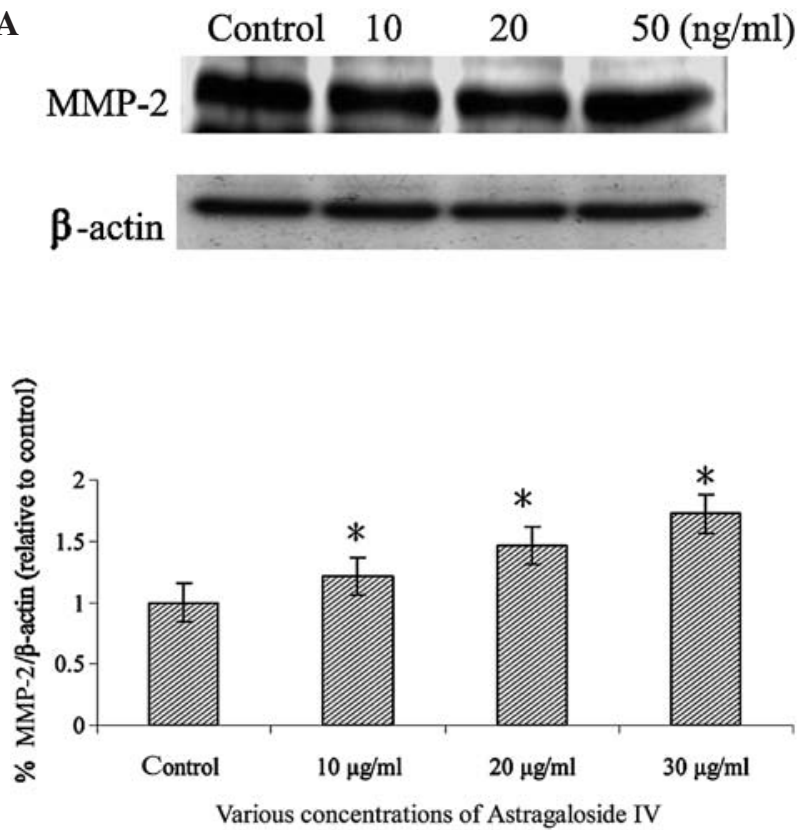
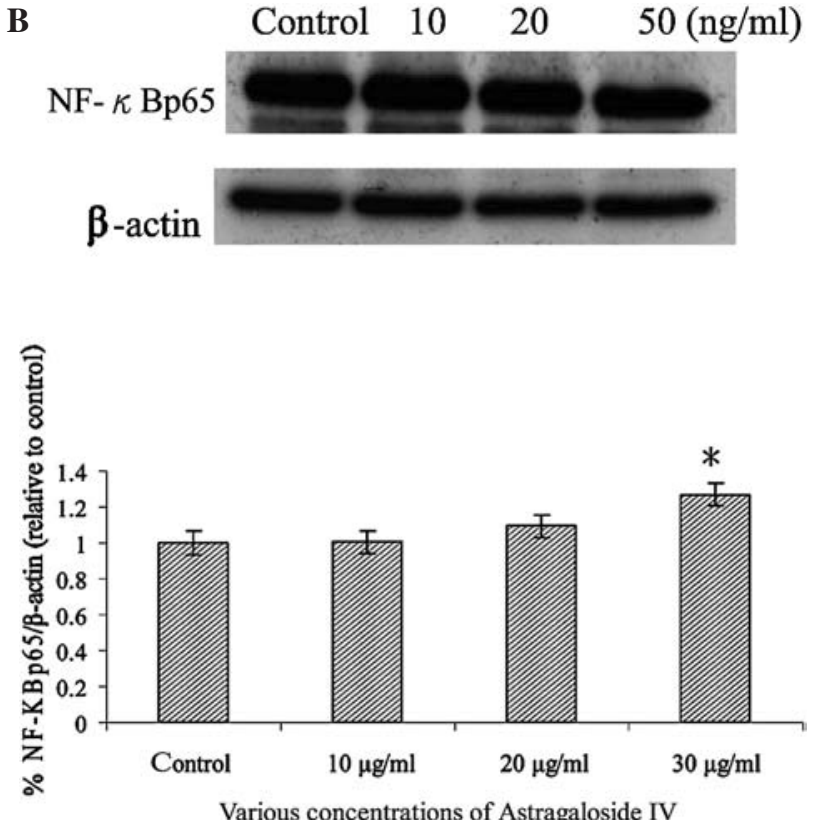

Figure 6. Protein expression of MMP-2 and NF-кBp65 in A549 cells after exposure to Astragaloside IV. A549 cells (2x106/ml) were treated with different Astragaloside IV concentrations of 10, 20 and $30 \mu \mathrm{g} / \mathrm{ml}$ for $24 \mathrm{~h}$ before being harvested by centrifugation. Total protein was prepared and determined as described in Materials and methods. Levels of (A) MMP-2 and (B) NF- $\mathrm{kBp} 65$ expression were estimated by Western blotting as described in Materials and methods. Protein expression of (A) MMP-2 was significantly increased after treatment with Astragaloside IV at concentrations of 10,20 and $30 \mu \mathrm{g} / \mathrm{ml}$ for $24 \mathrm{~h}$. The protein expression of (B) NF- $\mathrm{\kappa Bp} 65$ was significantly increased after treatment with Astragaloside IV at a concentration of $30 \mathrm{mg} / \mathrm{ml}$ for $24 \mathrm{~h}$. Each point is the mean $\pm \mathrm{SD}$ of three experiments. ${ }^{*} \mathrm{P}<0.05$.

Astragaloside IV of 10, 20, 50 and $100 \mathrm{ng} / \mathrm{ml}$ in the A549 cells respectively resulted in proliferation rates (relative to the control) of $96.85 \pm 1.12,95.63 \pm 0.83,93.92 \pm 0.84,95.27 \pm 0.57 \%$ after $24 \mathrm{~h} ; 98.86 \pm 1.56,95.71 \pm 0.59,94.09 \pm 0.68,93.44 \pm 0.5 \%$ after $48 \mathrm{~h}$; and $99.48 \pm 0.16,95.60 \pm 0.48,95.23 \pm 0.67$, $94.72 \pm 1.12 \%$ after $72 \mathrm{~h}$ (Fig. 1).
Effects of Astragaloside IV on VEGF and MMP-2 mRNA expression in A549 cells. RT-PCR revealed VEGF mRNA expression to be upregulated at Astragaloside IV concentrations of 20 and $50 \mathrm{ng} / \mathrm{ml}$ (Fig. 2). MMP-2 mRNA expression was upregulated at concentrations of 10, 20 and 50 ng/ml (Fig. 3). 
Cytotoxicity of Astragaloside IV in human lung cancer A549 cells. The results of the cell viability assay, visualized using a contrast-phase microscope at a magnification of x100 (Fig. 4A, $\mathrm{B}$ and $\mathrm{C}$ ), indicate that when A549 cells were exposed to increased Astragaloside IV concentrations of 0, 2.5, 5, 20 and $30 \mu \mathrm{g} / \mathrm{ml}$, the numbers of viable cells were $94.93 \pm 0.15$, $88.88 \pm 0.1,91.28 \pm 0.23$ and $91.86 \pm 0.15 \%$ at $24 \mathrm{~h} ; 95.48 \pm 1.53$, $96.79 \pm 3.4,95.07 \pm 1.97$ and $95.08 \pm 1.81 \%$ at $48 \mathrm{~h}$; and $93.94 \pm 4.61,95.47 \pm 8.55,93.73 \pm 5.63$ and $95.95 \pm 5.27 \%$ at $72 \mathrm{~h}$, respectively. This indicates that Astragaloside IV did not significantly inhibit the growth of A549 cells (Fig. 4D).

Effects of Astragaloside IV on the cell cycle. In order to determine the effects of Astragaloside IV on cell growth and apoptosis in A549 cells, cell cycle distribution was analyzed by flow cytometry. The results indicate that the percentage of cells in the sub-G1 phase did not increase after $48 \mathrm{~h}$ of treatment with Astragaloside IV concentrations of 10, 20 and $30 \mu \mathrm{g} / \mathrm{m}$ (Fig. 5).

Metastasis-associated protein expression. Astragaloside IVmediated cell metastasis was investigated by determining the expression of metastasis regulator proteins using Western blotting. The results indicate that protein expression of MMP-2 was significantly increased after $24 \mathrm{~h}$ of treatment with Astragaloside IV at concentrations of 10,20 and $30 \mu \mathrm{g} / \mathrm{ml}$ (Fig. 6A). The protein expression of NF-кBp65 was significantly increased after $24 \mathrm{~h}$ of treatment with Astragaloside IV at a concentration of $30 \mathrm{mg} / \mathrm{ml}$ (Fig. 6B).

\section{Discussion}

Astragalus membranaceus (family Leguminosae) is a genus widely distributed throughout the temperate regions of the world, principally across Europe, North America and Asia. Approximately 2000 species have been described (17). It has been reported that adjunctive therapy with an Astragaluscontaining herbal remedy (Fu-Zheng) protects adrenal cortical function, reduces gastrointestinal toxicity and ameliorates bone marrow suppression $(18,19)$, and Astragalus-containing herbal mixtures are commonly used in conjunction with chemotherapy to treat cancer patients (20).

Our results indicate that VEGF mRNA expression was upregulated by Astragaloside IV in human lung cancer A549 cells. VEGF is essential to vascularization at the very early stages of tumor formation and is a key promoter of metastasis (21). In many studies, VEGF expression in the primary tumor has been correlated with a greater risk of recurrence and a poor prognosis in non-small cell lung cancer (22).

Our results also demonstrate that Astragaloside IV increased MMP-2 mRNA and protein expression in the A549 cells. It is well documented that the MMPs play a central role in tumor invasion and angiogenesis (11), and the expression of MMP-2 is thought to be associated with the growth, invasion and metastasis of human lung adenocarcinoma cell lines $(12,23,24)$.

This is the first report to suggest that Astragaloside IV upregulates VEGF mRNA and MMP-2 mRNA and protein expression in human lung cancer A549 cells in vitro. This implies that Astragaloside IV may in fact increase the recur- rence and metastatic rates of lung cancer A549 cells. This issue requires further clinical study.

\section{Acknowledgements}

This study was supported by grants CCMP95-RD-206 and CCMP97-RD-011 from the Committee on Chinese Medicine and Pharmacy, Department of Health, Executive Yuan, Taiwan, R.O.C., and partially supported by the Chen-Han Foundation for Education.

\section{References}

1. Bensky D and Gamble A: Chinese Herbal Medicine: Materia Medica. Revised edition. Eastland Press, Seattle, WA, 1993.

2. Huang ZQ, Qin NP and Ye W: Effect of Astragalus membranaceus on T-lymphocyte subsets in patients with viral myocarditis. Chung Kuo Chung Hsi I Chieh Ho Tsa Chih 15: 328-330, 1995.

3. Peng T, Riesemann H and Kandolf R: The inhibitory effect of Astragalus membranaceus on coxsackie B3 virus RNA replication. Chin Med Sci J 10: 146-150, 1995.

4. Yoshida Y, Wang MQ, Shan BE and Yamashita U: Immunomodulating activity of Chinese medical herbs and Oldenlandia diffusa in particular. Int J Immunopharmacol 19: 359-370, 1997.

5. Zee-Cheng RK: Shi-quan-da-bu-tang (ten significant tonic decoctions), SQT. A potent Chinese biological response modifier in cancer immunotherapy, potentiation and detoxification of anticancer drugs. Methods Find Exp Clin Pharmacol 14: 725-736, 1992.

6. Lau BH, Ruckle HC, Botolazzo T and Lui PD: Chinese medicinal herbs inhibit growth of murine renal cell carcinoma. Cancer Biother 9: 153-161, 1994.

7. Cha RJ, Zeng DW and Chang QS: Non-surgical treatment of small cell lung cancer with chemo-radio-immunotherapy and traditional Chinese medicine. Chung Hua Nei Ko Tsa Chih 33: 462-466, 1994.

8. Hong YH: Oriental Materia Medica: A Concise Guide. Oriental Healing Arts Institute, Long Beach, 1986.

9. Ma XQ, Shi Q, Duan JA, Dong TT and Tsim KW: Chemical analysis of Radix Astragali (Huanggi) in China: a comparison with its adulterants and seasonal variations. J Agric Food Chem 50: 4861-4866, 2002

10. Chu SC, Chiou HL, Chen PN, Yang SF and Hsieh YS: Silibinin inhibits the invasion of human lung cancer cells via decreased productions of urokinase-plasminogen activator and matrix metalloproteinase-2. Mol Carcinog 40: 143-149, 2004.

11. Shiraga M, Yano S, Yamamoto A, Ogawa H, Goto H, Miki T, Miki K, Zhang H and Sone S: Organ heterogeneity of hostderived matrix metalloproteinase expression and its involvement in multiple-organ metastasis by lung cancer cell lines. Cancer Res 62: 5967-5973, 2000.

12. Gu J, Nishiuchi R and Sekiguchi K: Matrix metalloproteinase-2 is involved in A549 cell migration on laminin-10/11. Biochem Biophys Res Commun 296: 73-77, 2002.

13. Jurasz P, Sawicki G, Duszyk M, Sawicka J, Miranda C, Mayers I and Radomski MW: Matrix metalloproteinase 2 in tumor cellinduced platelet aggregation: regulation by nitric oxide. Cancer Res 61: 376-382,2001.

14. Li TM, Chen GW, Su CC, Lin JG, Yeh CC, Cheng KC and Chung JG: Ellagic acid induced p53/p21 expression, G1 arrest and apoptosis in human bladder cancer T24 cells. Anticancer Res 25: 971-979, 2005.

15. Chen HC, Hsieh WT, Chang WC and Chung JG: Aloe-emodin induced in vitro $\mathrm{G} 2 / \mathrm{M}$ arrest of cell cycle in human promyelocytic leukemia HL-60 cells. Food Chem Toxicol 42: 1251-1257, 2004.

16. Bradford MM: A rapid and sensitive method for the quantitation of microgram quantities of protein utilizing the principle of protein-dye binding. Anal Biochem 72: 248-254, 1976.

17. Davis AM: Crude protein, crude fiber, tannin, and oxalate concentrations of 33 Astragalus species. J Range Manag 35: 32-34, 1982.

18. Sun Y, Chang Y and Yu G: Effect of Fu-Zheng therapy in the management of malignant diseases. Chinese Med J 61: 97-101, 1981. 
19. Sun Y: Chinese medicinal herbs as biologic response modifiers In: Natural Immunity, Cancer and Biologic Response Modification. Lotzova E and Herberman R (eds). Karger, Basel, pp206-211, 1986.

20. Sun Y, Hersh E, Lee S, McLaughlin M, Loo T and Mavligit G Preliminary observations on the effects of the Chinese medicinal herbs Astragalus membranaceus and Ligustrum lucidum on lymphocyte blastogenic response. J Biol Response Mod 2: 227-237, 1983.

21. Saito H, Tsujitani S, Ikeguchi M, Maeta M and Kaibara N: Relationship between the expression of vascular endothelial growth factor and the density of dendritic cells in gastric adenocarcinoma tissue. Br J Cancer 78: 1573-1577, 1998.
22. Rosen LS: Clinical experience with angiogenesis signaling inhibitors: focus on vascular endothelial growth factor (VEGF) blockers. Cancer Control 9: 36-44, 2002.

23 Mase K, Iijima T, Nakamura N, Takeuchi T, Onizuka M, Mitsui T and Noguchi M: Intrabronchial orthotropic propagation of human lung adenocarcinoma - characterizations of tumorigenicity, invasion and metastasis. Lung Cancer 36: 271-276, 2002.

24. Zucker S, Lysik RM, Malik M, Bauer BA, Caamano J and Klein-Szanto AJ: Secretion of gelatinases and tissue inhibitors of metalloproteinases by human lung cancer cell lines and revertant cell lines: not an invariant correlation with metastasis. Int J Cancer 52: 366-371, 1992. 
